\title{
Preprint: Crowdsourcing and Analysing Wildlife Tourism Data from Photographs Shared on Social Media
}

\author{
Obelia Walker ${ }^{1}$ - https://orcid.org/0000-0001-8567-786X \\ Greg D. Simpson ${ }^{1,{ }^{\star}}$ - https://orcid.org/0000-0003-4926-5491 \\ Albert C. K. Teo 2,3 - https://orcid.org/0000-0002-8393-7696 \\ David Newsome ${ }^{1}$ - http://orcid.org/0000-0003-1482-6703
}

1 College of Science, Health, Engineering, and Education-Environmental and Conservation Sciences, Murdoch University, 90 South Street, Perth 6150, WA, Australia.

2 Faculty of Business, Economics and Accountancy, Universiti Malaysia Sabah (UMS), Jalan UMS, 88400, Kota Kinabalu, Sabah, Malaysia.

3 Borneo Eco Tours, Lot 1, Pusat Perindustrian, Kolombong Jaya, Jalan Kolombong, 88450 Kota Kinabalu, Sabah, Malaysia.

* Correspondence: G.Simpson@Murdoch.edu.au

\section{Abstract}

The first two decades of the $21^{\text {st }}$-century have seen the emergence of the modern citizen science movement, increased demand for niche eco and wildlife tourism experiences, and the willingness of people to voluntarily share information and photographs online. To varying extents, the rapid growth of these three phenomena has been driven by the availability of portable smart devices, access to the Web 2.0 internet from almost anywhere on the planet, and the development of applications and services, including social media/networking sites (SNSs). In addition, the number of peer-reviewed publications that explore how text and images shared on SNSs can be data-mined for academic research has surged in recent years. This systematic quantitative review has two goals. The first goal is to provide an oversight of how the photographs that ecotourists share online are contributing to wildlife tourism research. The second goal is to promote the emerging photovoice technique as a theoretical context for social research based on the photographs and comments that ecotourists share on SNSs. From the perspectives of community benefits, conservation behaviours, and environmental education, there are many similarities between authentic ecotourism experiences and quality ecological citizen science programs. Much of the literature regarding the theory and practice of citizen science reports on the difficulties of attracting, training, motivating and retaining community members. The synthesis of this review is that crowdsourcing wildlife and tourism data from comments and photographs that ecotourists share on SNSs is a credible method of research that provides a self-replenishing pool of citizen scientists.

Keywords: crowdsourcing; citizen science; ecotourism; Facebook; Flickr; photo-elicitation; Instagram; photovoice; social media; social networking sites; Twitter; wildlife conservation 


\section{Introduction}

Expanding the profile and scope of citizen science, increasing community participation, and innovatively leveraging available technologies are common themes in the citizen science theory and practice literature (Bonney, et al., 2009; Bonney, Cooper \& Ballard 2016; Eitzel, et al., 2017; Franzoni \& Sauermann 2014; Liberatore, et al., 2018; Soleri, et al., 2016). Access to the Web 2.0 internet, the development of portable smart devices, and the proliferation of software applications and content for mobile computing have facilitated the explosive growth of modern citizen science in the opening decades of the 21st-century (Dickinson, Zuckerberg \& Bonter 2010; Hampton, et al., 2011; Huertas \& Marine-Roig 2015; Nemec Rudež \& Vodeb 2015; Silvertown 2009; van Dijck 2013). Engagement; public participation; democracy; "community empowerment"; "adoption of conservation behaviours"; "science learning"; and sharing of knowledge and information are important elements of modern citizen science (Bonney, et al., 2009; Bonney, Cooper \& Ballard 2016: 2; Eitzel, et al., 2017; Soleri, et al., 2016).

Concurrent with the emergence of modern citizen science, the World Wide Web was created in 1991 and then Web 2.0 emerged in the $21^{\text {st }}$-century, which supported the development and proliferation of social media platforms such as Wikipedia - 2001; Myspace - 2003; Facebook - 2004; Flickr - 2004; YouTube - 2005; and Twitter - 2006 (Hampton, et al., 2011; van Dijck 2013). The academic literature now commonly refers to these social media platforms as social networking sites (Hampton, et al., 2011; Noh, Lee \& Hwang 2017).

The past two decades have also seen rapid growth in the ecotourism industry, with a growing desire to reconnect with nature and to experience up-close and personal interactions with iconic and charismatic wildlife being significant drivers of the industry (Orsini \& Newsome, 2013; Patroni, et al., 2017; Patroni, Simpson \& Newsome 2018). Each year, millions of people are now engaging in travel that incorporates visiting natural areas to interact with and take photographs of wildlife (Curtin 2009; Curtin \& Kragh 2014; UNWTO 2017). Authentic quality ecotourism experiences, which includes wildlife tourism, are characterised by being nature-based, ecologically sustainable, environmentally educative, contributing to conservation, and beneficial for local communities (Fennell 2001 \& 2008; Newsome, Moore \& Dowling 2013; Weaver 2008). An increasing number of the tourists who are seeking authentic and ecologically sustainable ecotourism are sharing their experiences on social networking sites (SNSs) such as Facebook, Flickr, Instagram, TripAdvisor and Twitter (Prakash, et al., 2017; Prakash, et al., 2018; Zavodna \& Zavodny Pospisil 2018).

Given the alignment between ecological citizen science and the desire of ecotourists to share their quality ecotourism experiences online, there is much scope for engaging ecotourists as citizen scientists. This can be achieved by collecting and analysing the photographs and comments that tourists share on SNSs. Such an approach aligns with the methods of citizen science. Shared photographs, especially if geotagged (Orsi \& Geneletti 2013; Oteros-Rozas, et al., 2017; Senaratne, et al., 2017), along with the comments of ecotourists, fall into the category of crowdsourced "volunteered geographic information" citizen science data (Eitzel, et al., 2017; Sieber \& Haklay 2015: 1). Correspondingly, it is pertinent to appreciate that "photovoice", a technique originally used in anthropology to extract meaning from photographs, is a technique that is now being increasingly utilised in wildlife conservation and tourism research (e g. Wang \& Burris 1997: 1; Tonge, et al., 2013; Hansen 2016; Willemen, et al., 2015). 
Because of the growing body of research that uses comments and photographs shared online by tourists for investigating wildlife tourism situations, this review considers the mining and analysis of this data in the context of citizen science theory and practice. Furthermore, in exploring both the use of tourist-generated photography and photovoice techniques within the context of wildlife research and nature-based tourism experiences, this systematic quantitative literature review (Pickering \& Byrne 2014) establishes the credibility of the methods that underpin this novel emerging approach for crowdsourcing citizen science data.

\section{Photography as a research method}

Photography is a long-established tool in scientific research, with a strong foundation in anthropology. The cameras ability to create a permanent visual record of a moment in time makes it capable of achieving accurate and automatic documentation (Basil, 2011; Collier, 1957). The recorded information can then be explored beyond a literal image to also investigate emotive and social elements. Over time, as society has become increasingly digital and the taking of photographs has become instant, the application of this approach has gained greater relevance and momentum in modern research (Zhang, et al., 2012). The photo-elicitation technique epitomised this evolving application of photography in social research. Traditionally, photo-elicitation is based on the idea of inserting a photograph into a research interview and asking interviewees to comment on the photographs. Harper (2002) hypothesised that the basis behind this process is that the parts of the brain involved in processing visual information are evolutionary older than the parts involved in processing verbal information. Harper (2002) further speculated that this causes our discussion around images to evoke deeper elements of consciousness than through verbal inquiry alone.

The photovoice technique developed by Wang and Burris (1997) branches off from photoelicitation and empowers participants to engage more deeply in the process through the requirement that photographs be participant-generated as opposed to researcher-generated. Photovoice puts emphasis on action-orientated results (Given, et al., 2011) by giving participants control over the selection and generation of photographs and then using the insight drawn from this process to influence management on a particular issue (Miller, et al., 2016). At its core, photovoice provides a process for participants to amplify their voices in order to influence and direct change. This process is particularly useful for engaging groups who may have difficulty articulating their views (e.g. second language learners), thereby increasing the scope of participation (Given, et al., 2011). It is important to note, however, that photographs alone cannot function as a data set and that discussion on and around the images is required to establish meaning and relevance (Given, et al., 2011).

One particular aspect of this review explores the adoption of a modified application of photovoice (Yi-Frazier, et al., 2015), incorporating the use of user-generated photographs uploaded to online image-sharing platforms with the analysis of associated captions and comments providing the basis for discussion. This adaptation of the photovoice method reflects today's modern world and the evolving nature of photography, community discussion and social media (Yi-Frazier, et al., 2015; Zeglin \& Mitchell, 2014). Rather than providing participants with cameras and asking them to photograph a topic, this modified approach to photovoice analyses photographs that have been taken and shared online. In doing so, this overcomes limitations in respect to resources, funding and time (Given, et al., 2011). Furthermore, this crowdsourcing approach provides an alternative to using directed surveys, which can also be expensive to execute and are generally conducted on limited spatial and 
temporal scales (Barve 2014; Hausmann, et al., 2017a; Richards \& Friess, 2015; Wood, et al., 2013).

When crowdsourcing data is used in this way it can be difficult to determine the source, particularly within a social network setting. Whilst this review article focuses on touristgenerated photography, whereby a tourist is defined as "one who ventures away from home, alone or in a group, to see or do something that is unusual relative to the daily round of life" (Chalfen 1979: 437), this review also encompasses photographs generated by other groups such as members of the general public. The broad nature of the term 'tourist' makes it difficult to isolate tourists within an online setting without knowing their place of origin. However, this limitation is largely overcome by the content of the photographs themselves. Given that photographs taken in a national park setting or of unique/charismatic wildlife are closely associated with a wildlife tourism experience (Newsome Moore \& Dowling 2005), it is safe to assume that a majority of these photographs are generated by people engaged in an ecotourism experience. This view is further reinforced by Chalfen (1979) who describes the activity of taking photographs as one of the most common tourist attributes.

Applying photovoice and tourist-generated photography to wildlife tourism research is opportunistic in drawing on the natural willingness of tourists to take and share photographs during a wildlife experience (Hansen 2016; Willemen, et al., 2015). Such photographs and accompanying narratives can then be used to answer questions about wildlife tourism experiences such as (1) ecological aspects of the target species, (2) the location of the wildlife and (3) circumstances under which the wildlife was appreciated and how tourists felt about the experience (Hansen 2016).

\section{Method}

\section{Systematic literature review method}

A systematic quantitative literature review of recent studies on the application of photovoice and tourist-generated photography to wildlife tourism research was carried out using the technique of Pickering and Byrne (2014) and Pickering, et al., (2015). This method provides a more straightforward and systematic approach than the more traditional narrative method and aims to ameliorate potential biases by structuring the literature collection process in a series of defined and reproducible steps. By following the criteria of this approach in the identification of relevant literature, this review provides a comprehensive overview of the current peer reviewed articles.

Research articles were obtained using the Murdoch University Findit online-search tool, which searches globally on over 100 subscribed databases, including Scopus and Web of Science. The Findit search tool also provides access to articles that may be available through BONUS+ or ArticleReach. The initial review parameters (Figure 1) included peer reviewed articles from the last five years available in electronic format. This provided a starting point for the review and, given the nature of the topic as being a relatively new field, captured a high portion of the most relevant literature. The Findit online tool was searched in May 2017 and again in February 2018 using multiple combinations of keywords. The terms 'wildlife' and 'tourism' were searched in combination with 'photo' and/or 'social media'. The inclusion of the search term 'photo' was useful in not only capturing studies that utilized photographs, but also studies that used photovoice and photo-elicitation approaches. The reference lists from these initial articles were then cross-checked to locate additional and older foundation publications not identified by the electronic database search. Reference 
lists of additional articles were also cross-checked until no new articles were being identified (Figure 1).

\section{Screening and data extraction}

The keyword searches identified a total of 422 articles, which were subsequently screened to reject articles that (1) were written in a language other than English, (2) did not incorporate the use of photographs, (3) incorporated the use of photographs gathered and analysed exclusively by researchers or (4) could not be applied to wildlife tourism or naturebased tourism. Whilst the application of tourist-generated photography to wildlife tourism research is the primary focus of this review, articles discussing nature-based tourism are also included, due to the strong overlap in these fields of research. Newsome, Moore and Dowling (2005 \& 2013) highlight the important role that wildlife presence and observation plays in the recreational experience of visitors to natural areas, which validates the decision to include these articles. The decision to reject articles that used photographs gathered and analysed exclusively by researchers was necessary to exclude the large volume of wildlife studies that utilize techniques such as camera-trapping. Such studies were not relevant to the topic of this review, as they did not incorporate the use of photographs generated by tourists or members of the public. In addition, it is a requirement of the photovoice methodology that photographs be participant-generated, further supporting the need to exclude such studies. After the consecutive crosschecking of reference lists, 50 articles were selected for further analysis.

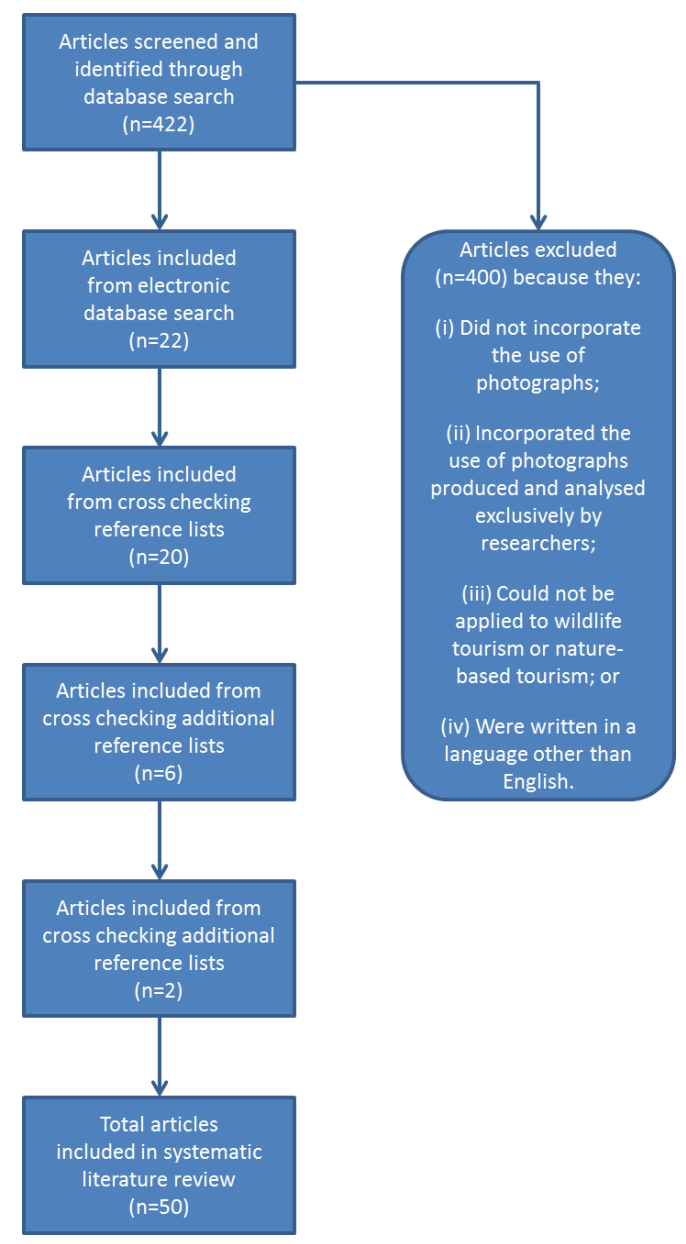

Figure 1: Systematic literature review process with the number of articles that were located, retained, and discarded shown at each stage. 


\section{Key variables and questions to assess}

The 50 selected articles were quantitatively assessed to provide a structured overview of the published literature. Data collected from each article included publication information (author(s) and journal), temporal and geographic information (country and continent), whether the article was research based or a review article, target species (for ecological studies), who was providing the photos, what type of online platform used to access photographs, whether the study method was qualitative or quantitative, sample size (number of photographs), sampling period, whether geotagged photographs were used and finally a summary of the main findings of the study. It is important to note that in some cases where researchers crowdsourced information from online platforms, the actual location of the study site was different to the attributed location of the research(ers). Subsequently, for the purpose of this review, location was defined as the locality of the study site. These variables, including descriptions of relevant categories, are outlined in Table 1.

Table 1: Variables extracted from articles included in the systematic review.

\begin{tabular}{|c|c|c|}
\hline Variable & Description/ List of Categories & Data type \\
\hline Author (year) & & Text \\
\hline Journal & & Text \\
\hline Location of study & & Text \\
\hline Target species & & Text \\
\hline Focus of study & & Text \\
\hline $\begin{array}{l}\text { Photographs } \\
\text { uploaded/taken } \\
\text { by }\end{array}$ & $\begin{array}{l}\text { General Public, Tourists, Researchers and General } \\
\text { Public, Researchers and Tour Operators }\end{array}$ & Categorical \\
\hline $\begin{array}{l}\text { Online platform: } \\
\text { Dedicated vs SNS }\end{array}$ & $\begin{array}{l}\text { Dedicated, SNS, Other, Dedicated and SNS, } \\
\text { Dedicated and Other, SNS and other, Dedicated and } \\
\text { SNS and Other }\end{array}$ & Categorical \\
\hline $\begin{array}{l}\text { Name of dedicated } \\
\text { platform }\end{array}$ & $\begin{array}{l}\text { Wildbook, Wildbook for Whale Sharks, iNaturalist, } \\
\text { eBird, Pic4Turtle, TORSOOI, Waarnemingen, Whale } \\
\text { shark photo library }\end{array}$ & Categorical \\
\hline Name of SNS & $\begin{array}{l}\text { Flickr, Youtube, Instagram, Facebook, Vimeo, } \\
\text { TripAdvisor, Twitter, Panoramio, Linkedln }\end{array}$ & Categorical \\
\hline Name of other & $\begin{array}{l}\text { Wikipedia, PPGIS, OpenStreetMap, Google Earth, } \\
\text { GBIF, Map of Life, NBN }\end{array}$ & Categorical \\
\hline Method & Quantitative, Qualitative, Both & Categorical \\
\hline $\begin{array}{l}\text { Review or } \\
\text { research paper }\end{array}$ & Review, Research, Both & Categorical \\
\hline $\begin{array}{l}\text { Sample size (Num. } \\
\text { of photos) }\end{array}$ & $\begin{array}{l}\text { Less than } 50,50-100,100-500,500-1000, \\
1000-10000, \text { Greater than } 10000\end{array}$ & Categorical \\
\hline Sample period & $\begin{array}{l}\text { Less than } 1 \text { month, } 1-6 \text { months, } 6 \text { months - } 1 \text { year, } 1-2 \\
\text { years, } 2-5 \text { years, greater than } 5 \text { years }\end{array}$ & Categorical \\
\hline Geotagging & Were geotagged photographs used/ discussed? & Yes/ No \\
\hline Main findings & & Text \\
\hline
\end{tabular}




\section{Results}

The following sections report on the results of the systematic quantitative literature review whereby sample size $(n)$ is expressed as the number of relevant peer reviewed articles.

\section{Overview of research characteristics}

After four iterations of the search process, a total of 50 peer reviewed articles reporting on the application of photovoice and tourist-generated photography to wildlife tourism research were analysed. There has been increasing academic interest in this research topic in the last three years (Figure 2), with a total of 11 articles (22\%) published in the 2016 calendar year. Geographically, the research is spread over 20 countries (Figure 3) and 6 continents (Figure 4). The majority of these studies were from Australia $(n=11 ; 22 \%)$ and the United States of America $(n=11 ; 22 \%)$. The only other countries with multiple reported studies were the United Kingdom ( $n=3 ; 6 \%)$, South Africa $(n=2,4 \%)$ and Finland $(n=2,4 \%)$.

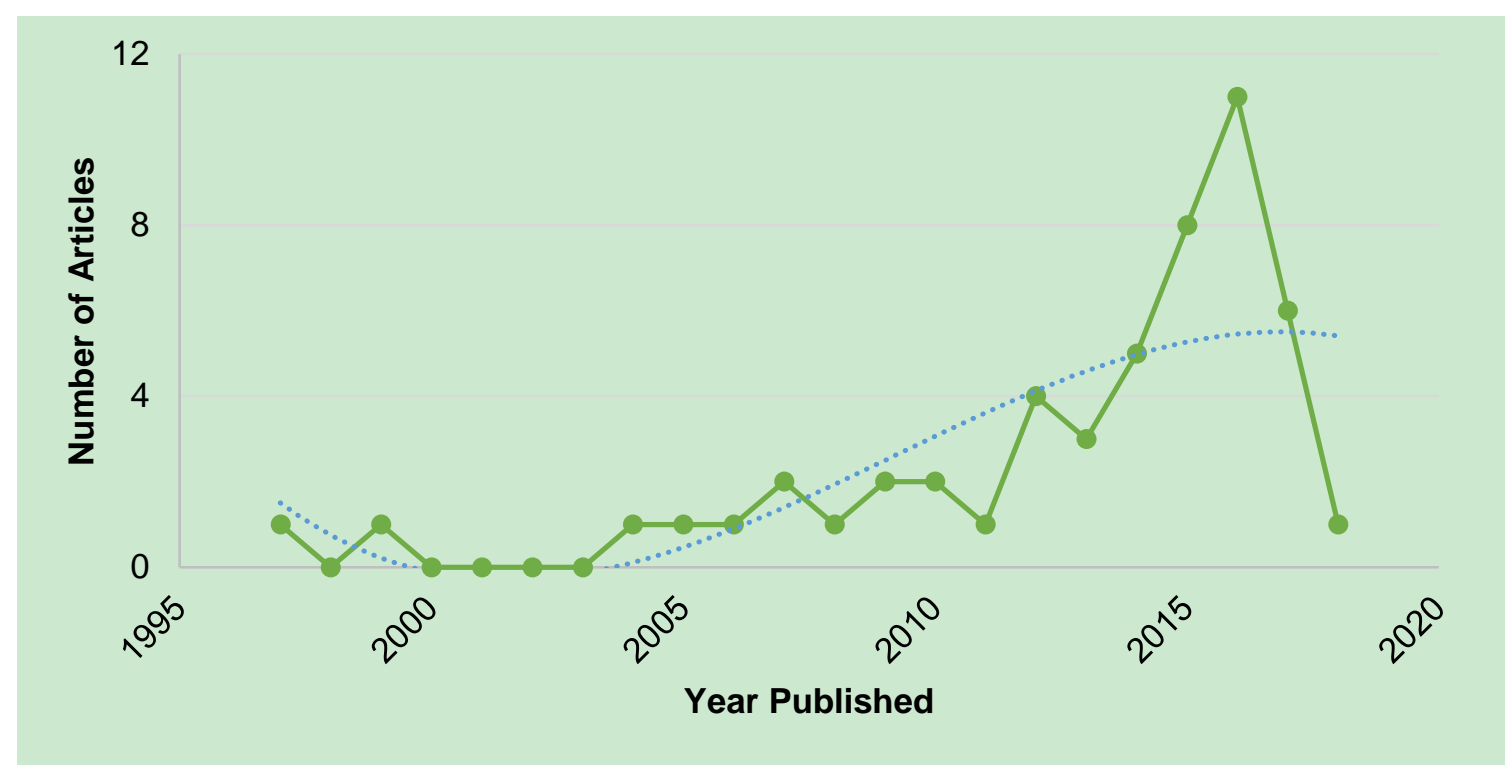

Figure 2: Number of peer reviewed articles based on photographs sourced from online platforms published each year.

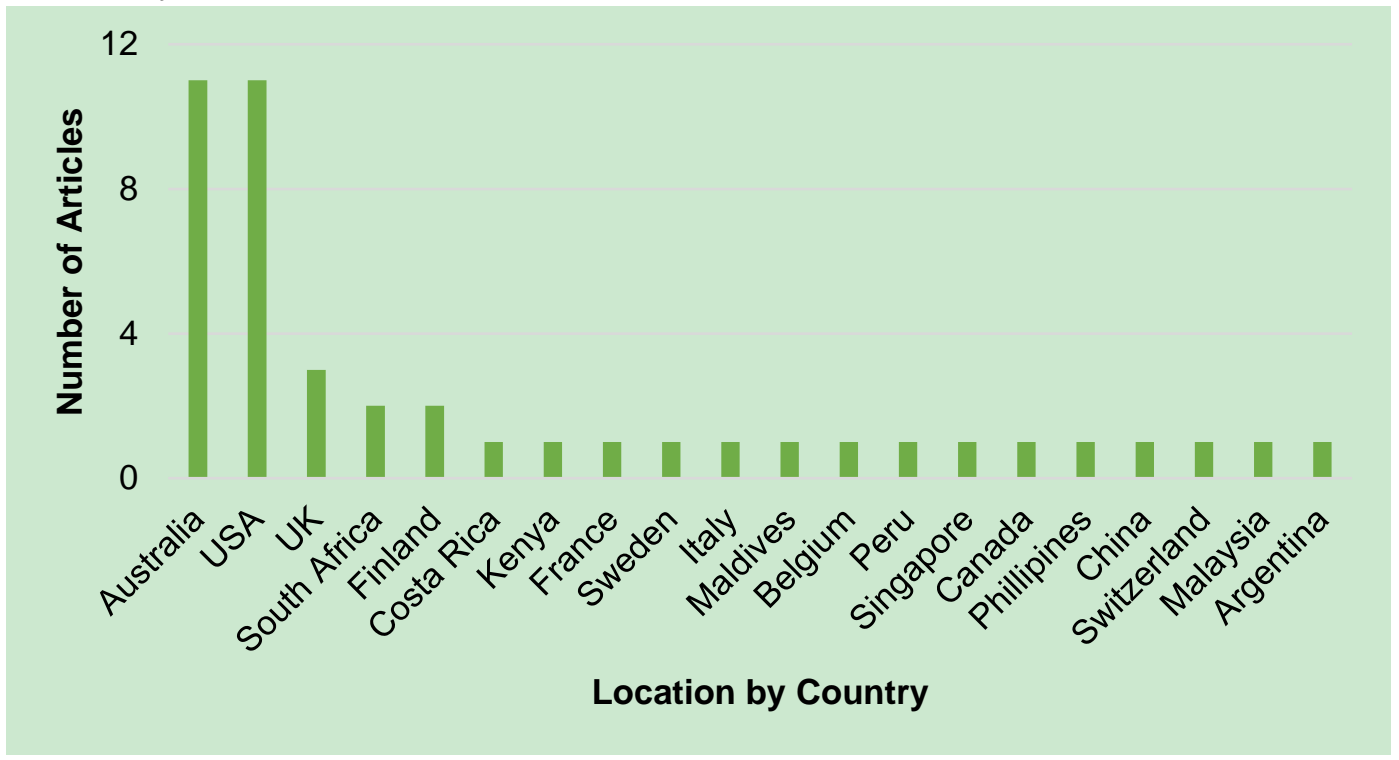

Figure 3: Geographic distribution of study locations reported in peer reviewed articles based on photographs sourced from online platforms by country. 


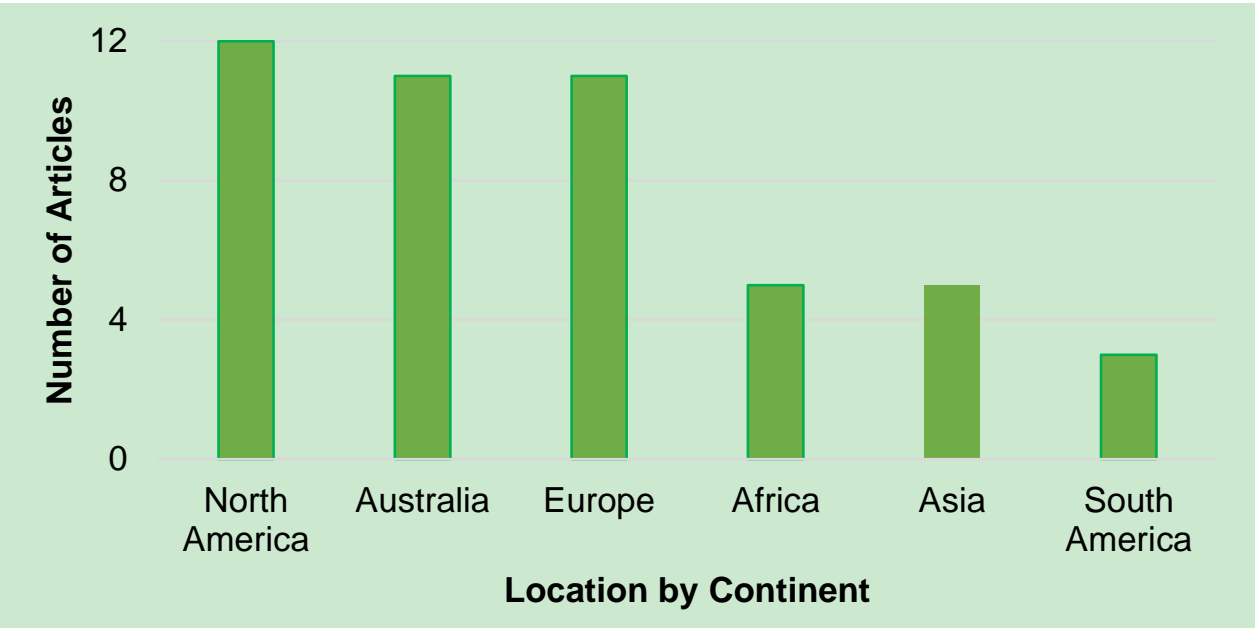

Figure 4: Geographic distribution of study locations reported in peer reviewed articles based on photographs sourced from online platforms by continent.

Photographs were predominantly sourced from people identified as the general public $(n=31$; $65.96 \%)$ and then from people identified as tourists ( $n=13 ; 27.66 \%)$. Combinations of contributors were included in cases where researcher-generated photos were also incorporated (Figure 5). Two articles used photographs generated by the general public in combination with researchers (4.26\%) and another used photographs generated by tour operators in combination with researchers $(2.13 \%)$.

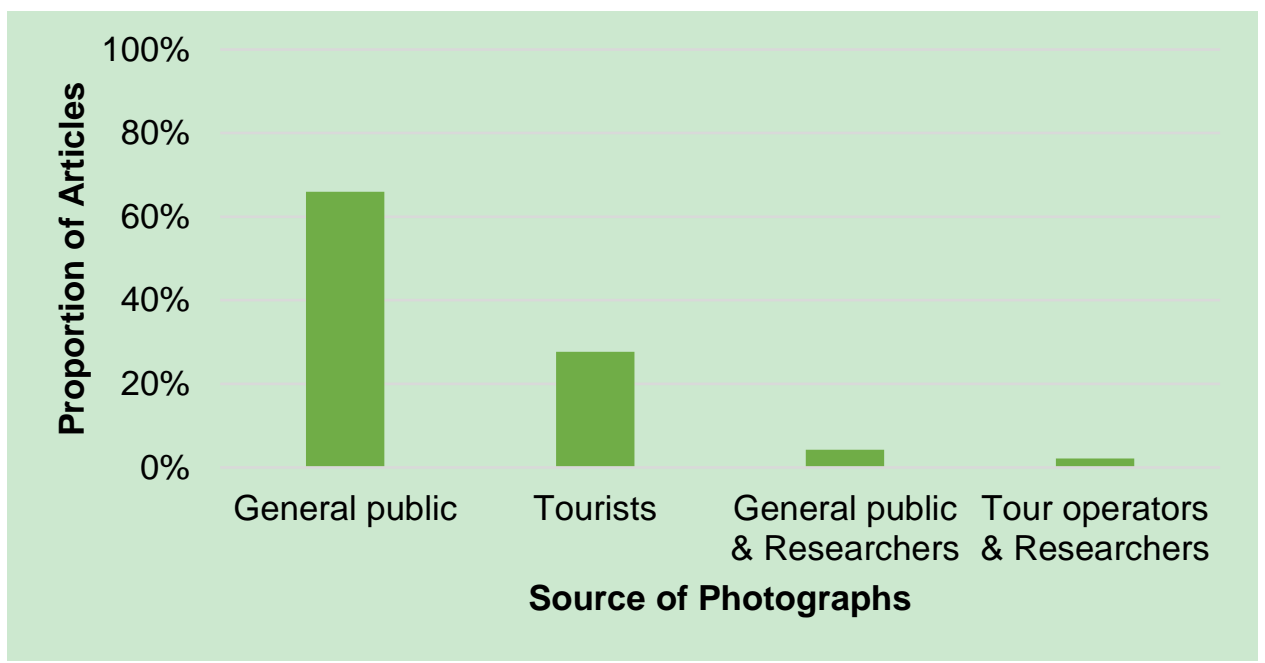

Figure 5: Who generated the photographs on which the peer reviewed articles were based?

Of the 50 articles analysed, the majority were research studies $(n=40 ; 80 \%)$ with five articles being exclusively review based (10\%). In addition, the five research articles that featured their own dedicated literature review section were analysed separately and these accounted for $10 \%$ of the literature. With respect to method, 31 studies adopted a quantitative approach (62\%), ten used a qualitative approach (20\%) and nine studies used a combination of both (18\%). The incorporation of geotagged photographs (with locational data stored in the images EXIF file) was detected in $59.42 \%$ of studies that collected data from online platforms. With respect to the types of online platforms used, 25 studies exclusively collected data from SNSs whilst nine articles exclusively accessed photographs from a dedicated platform (Table 2). The most commonly used SNS by studies was Flickr $(n=23)$, followed by Instagram $(n=7)$ and Facebook and Twitter equally $(n=6)$ (Table 2). 
Table 2: Range of online platforms utilised in studies to source photographs. Some articles referred to multiple platforms and for the purpose of this table are reported as separate 'studies'.

\begin{tabular}{|c|c|c|}
\hline \multicolumn{3}{|c|}{ Dedicated Platforms - Total of 15 Articles } \\
\hline Platform & $\begin{array}{l}\text { Num. of } \\
\text { Studies }\end{array}$ & Authors \\
\hline $\begin{array}{l}\text { Wildbook for Whale } \\
\text { Sharks }\end{array}$ & 8 & $\begin{array}{l}\text { Araujo, et al., 2016; Arzoumanian, et al., 2005; Davies, et } \\
\text { al., 2012; Holmberg, et al., 2008; Holmberg, et al., 2009; } \\
\text { Norman 1999; Norman, et al., 2016; Pearson, et al., } 2016\end{array}$ \\
\hline BeeWatch & 2 & Pearson, et al., 2016; van der Wal, et al., 2015 \\
\hline iNaturalist & 2 & Dickinson, et al., 2012; White, et al., 2015 \\
\hline Wildbook & 2 & Dunbar, et al., 2016; Parham 2015 \\
\hline Waarnemingen & 1 & Vantieghem, et al., 2016 \\
\hline Pic4Turtle & 1 & Dunbar, et al., 2016 \\
\hline eBird & 1 & Dickinson, et al., 2012 \\
\hline TORSOOI & 1 & Carpentier, et al., 2016 \\
\hline \multicolumn{3}{|c|}{ Social Networking Sites - Total of 32 Articles } \\
\hline Platform & $\begin{array}{l}\text { Num. of } \\
\text { Studies }\end{array}$ & Authors \\
\hline Flickr & 23 & $\begin{array}{l}\text { Araujo, et al., 2016; Barry 2014; Barve 2014; Davies, et } \\
\text { al., 2012; Di Minin, et al., 2015; Hausmann, et al., 2017a; } \\
\text { Keeler, et al., 2015; Kirkhope, et al., 2010; Levin, et al., } \\
\text { 2015; Levin, et al., 2017; Pearson, et al., 2016; Richards \& } \\
\text { Friess 2015; Sessions, et al., 2016; Sonter, et al., 2016; } \\
\text { Stafford, et al., 2010; Straumann, et al., 2014; Tenkanen, } \\
\text { et al., 2017; van Zanten, et al., 2016; Walden-Schreiner } \\
\text { 2017; Walden-Schreiner, et al., 2018; Willemen, et al., } \\
\text { 2015; Wood, et al., 2013; Zhang, et al., } 2012\end{array}$ \\
\hline Instagram & 7 & $\begin{array}{l}\text { Di Minin, et al., 2015; Hausmann, et al., 2017a; } \\
\text { Hausmann, et al., 2017b; Heikinheimo, et al., 2017; } \\
\text { Pearson, et al., 2016; Tenkanen, et al., 2017; van Zanten, } \\
\text { et al., } 2016\end{array}$ \\
\hline Facebook & 6 & $\begin{array}{l}\text { Araujo, et al., 2016; Di Minin, et al., 2015; Dickinson, et al., } \\
\text { 2012; Pearson, et al., 2016; Stafford, et al., 2010; White, } \\
\text { et al., } 2015\end{array}$ \\
\hline Twitter & 6 & $\begin{array}{l}\text { Di Minin, et al., 2015; Palomino, et al., 2016; Pearson, et } \\
\text { al., 2016; Roberge 2014; Tenkanen, et al., 2017; White, et } \\
\text { al., } 2015\end{array}$ \\
\hline Youtube & 3 & $\begin{array}{l}\text { Araujo, et al., 2016; Davies, et al., 2012; Di Minin, et al., } \\
2015\end{array}$ \\
\hline TripAdvisor & 2 & Cong, et al., 2014; Lu \& Stepchenkova 2012 \\
\hline Vimeo & 1 & Araujo, et al., 2016 \\
\hline Panoramio & 1 & van Zanten, et al., 2016 \\
\hline Linkedln & 1 & Di Minin, et al., 2015 \\
\hline \multicolumn{3}{|c|}{ Other Platforms - Total of 4 Articles } \\
\hline Platform & $\begin{array}{l}\text { Num. of } \\
\text { Studies }\end{array}$ & Authors \\
\hline Wikipedia & 1 & Levin, et al., 2017 \\
\hline PPGIS & 1 & Levin, et al., 2017 \\
\hline OpenStreetMap & 1 & Levin, et al., 2017 \\
\hline Google Earth & 1 & Orsi \& Geneletti 2013 \\
\hline GBIF & 1 & White, et al., 2015 \\
\hline Map of Life & 1 & White, et al., 2015 \\
\hline NBN & 1 & van der Wal, et al., 2015 \\
\hline
\end{tabular}


A separate analysis classified articles into three categories: (1) ecological studies on wildlife, (2) social studies on people's interactions with wildlife and natural areas or (3) incorporating elements of both (Figure 6). The number of yearly publications across all three categories have been shown to increase over recent years, with the majority of ecological studies ( $n=14,70 \%$ ), social studies ( $n=24,85.71 \%)$ and combined studies ( $n=2,100 \%)$ being published after and including 2010 (Figure 7). The analysis revealed an overall bias towards social research studies $(n=28 ; 56 \%)$ in the application of tourist-generated photography. Studies from North America focused on social research, primarily relating to visitation rates and tourist perceptions (Figure 8). In contrast, studies from Australia predominantly applied tourist-generated photography to ecological research (on whale-sharks), with these accounting for $63.64 \%(n=7)$ of the Australian studies. Ecological studies from Asia (which also focused exclusively on whale sharks) represented $40 \%(n=2)$ of the total studies from Asia (Figure 9), whilst $60.00 \%(n=3)$ were social science based. Research from Europe showed an even distribution between social $(n=6)$ and ecological $(n=5)$ studies.

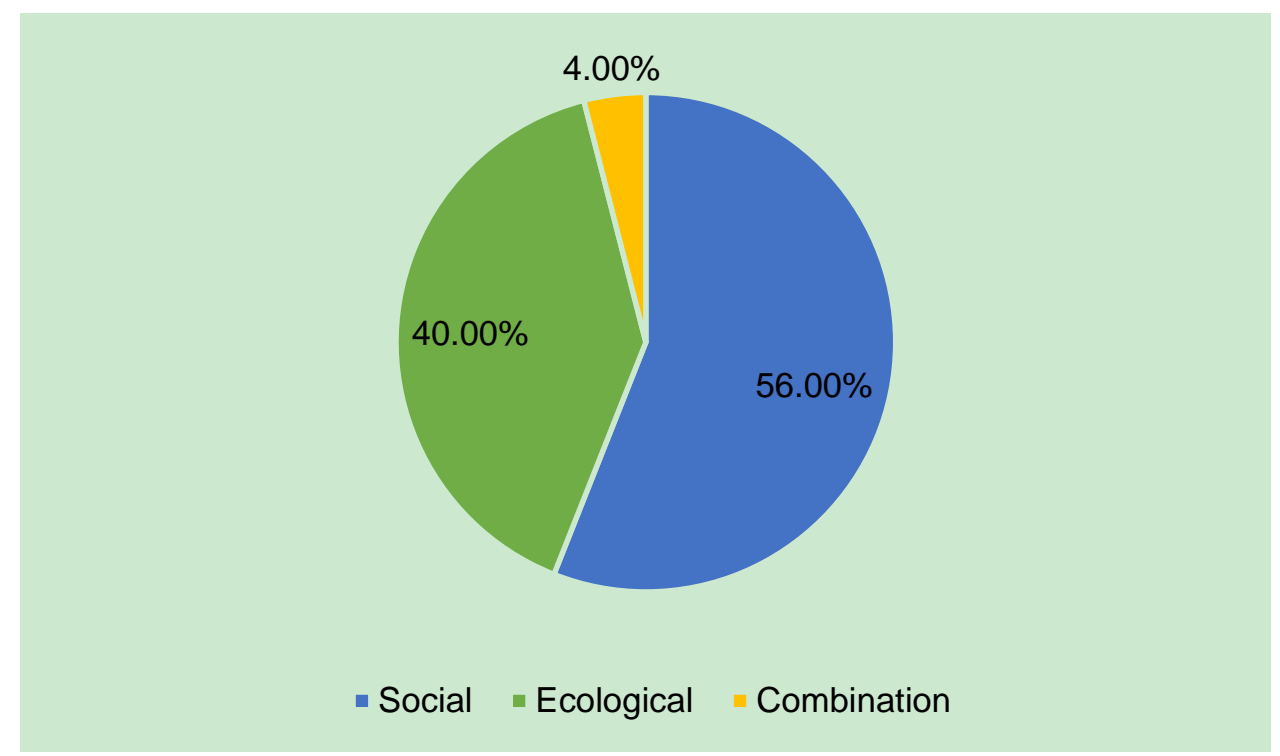

Figure 6: Research focus of peer reviewed articles based on photographs sourced from online platforms.

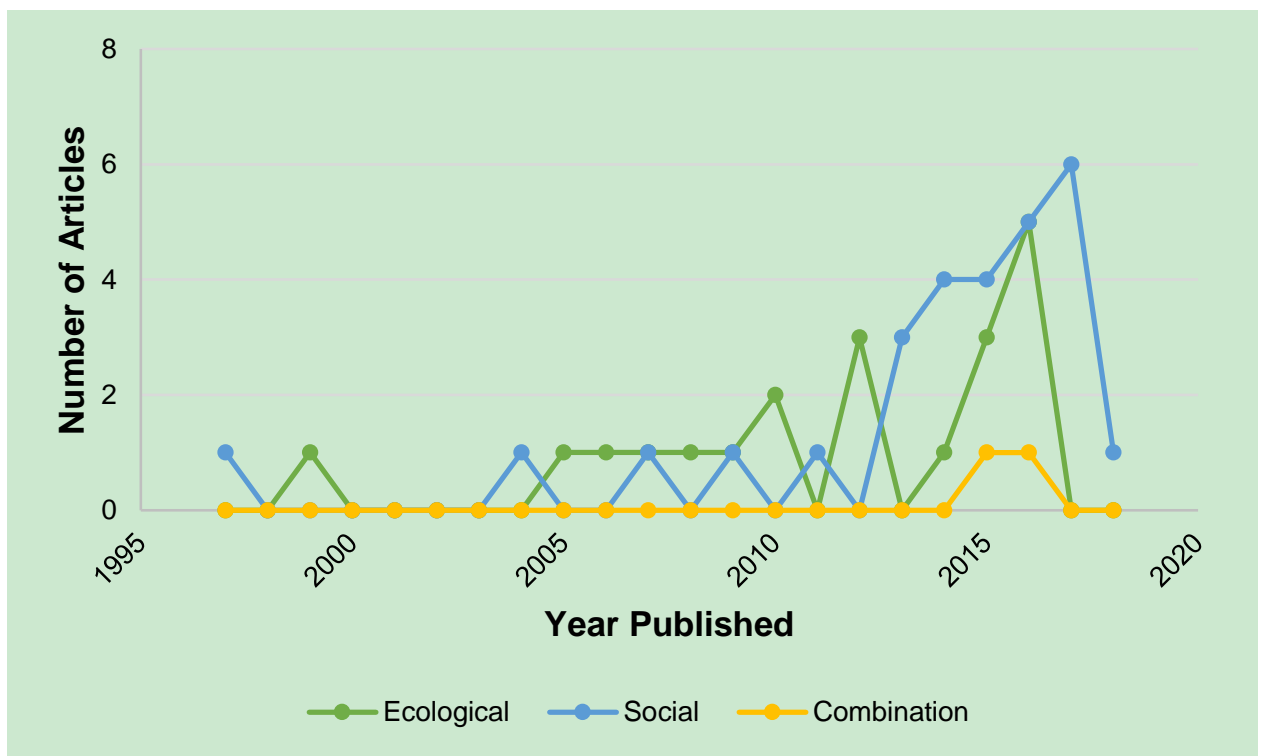

Figure 7: Research focus of peer reviewed articles based on photographs sourced from online platforms. 


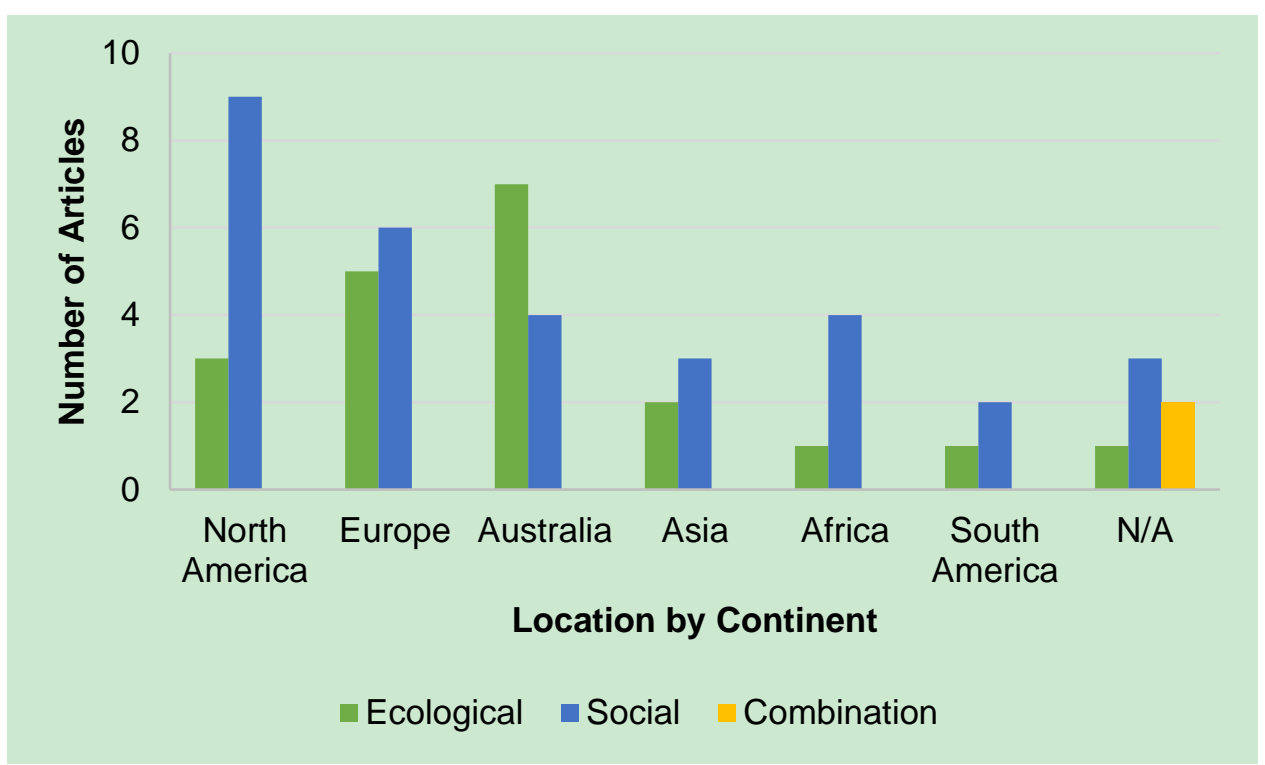

Figure 8: Geographic distribution of study locations of peer reviewed articles based on photographs sourced from online platforms by continent and focus of study. N/A represents studies without a defined study site (typically being review articles)

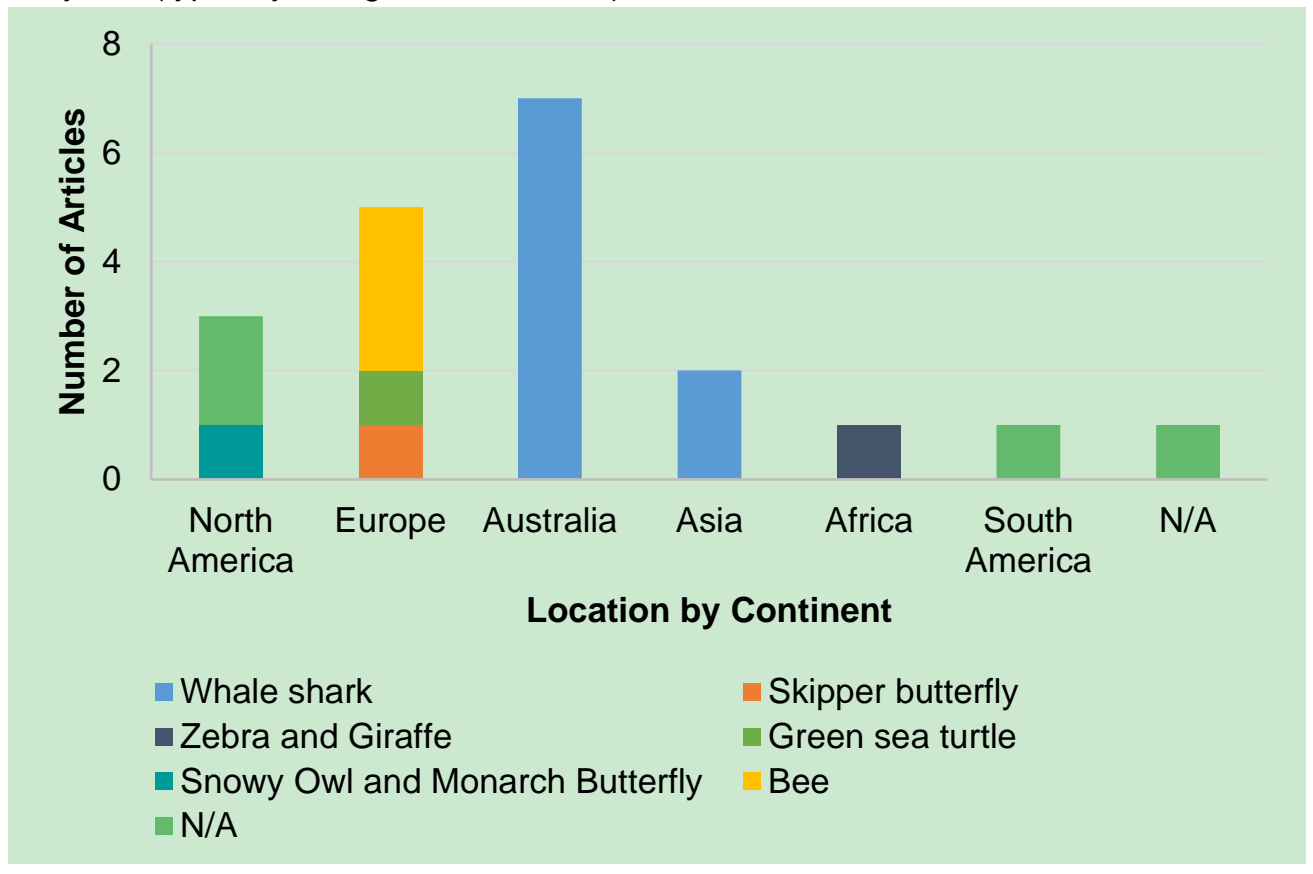

Figure 9: Geographic distribution of locations of ecological studies based on photographs sourced from online platforms by continent and target species. N/A represents ecological studies not having a specific target species.

Sample size of the reported studies was analysed from the perspective of both duration of study (Figure 10) and the number of photos collected (Figure 11). The majority of studies had data collection periods of greater than five years (45.71\%), but there is evidence of a bimodal nature for study length with $37.15 \%$ of studies running for less than one year (Figure 10). The reported studies analysed a large number of photographs (Figure 11) with a majority (68.76\%) analysing more than 1000 photographs and $84.39 \%$ of studies analysing more than 500 photographs. The relationship between the number of collected photographs and platform type (i.e. dedicated vs. SNS) was also analysed and revealed that studies using SNSs typically returned larger datasets (Figure 12). 


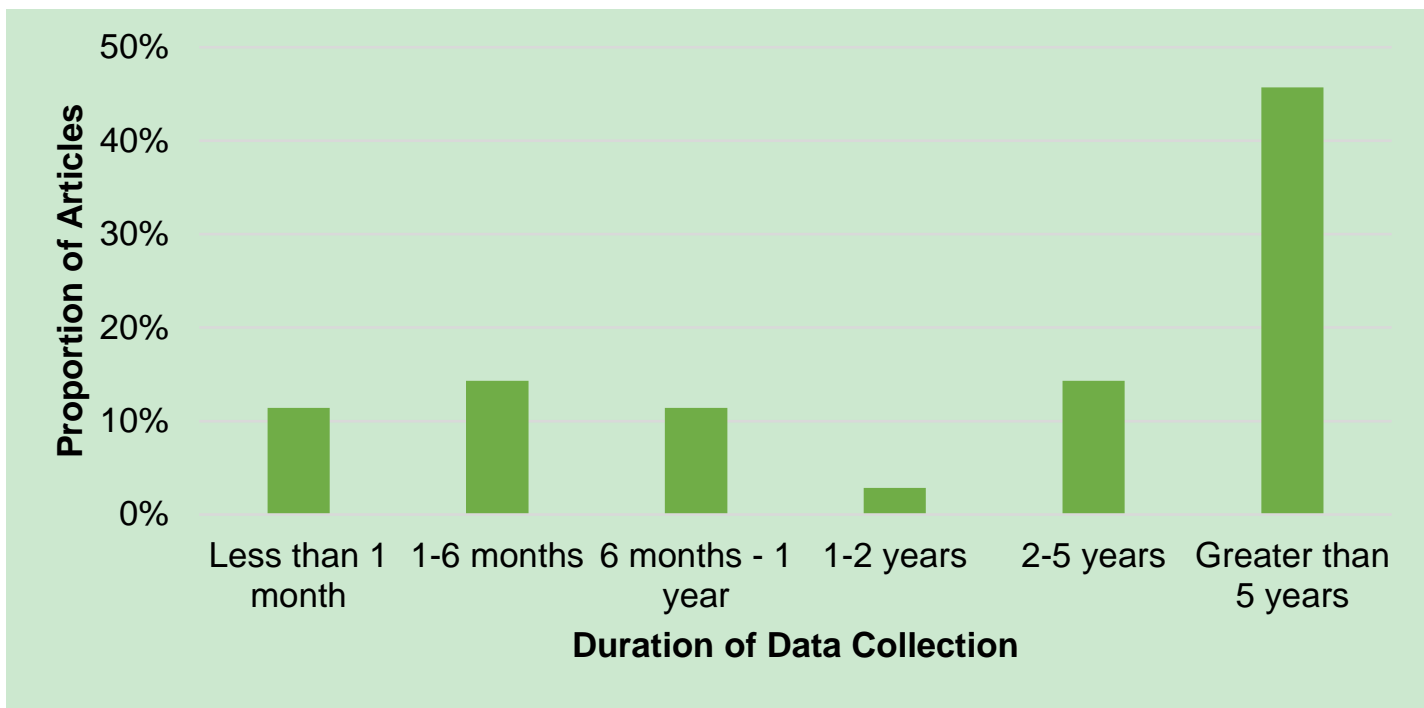

Figure 10: Duration of the studies based on photographs sourced from online platforms as reported in the peer reviewed articles.

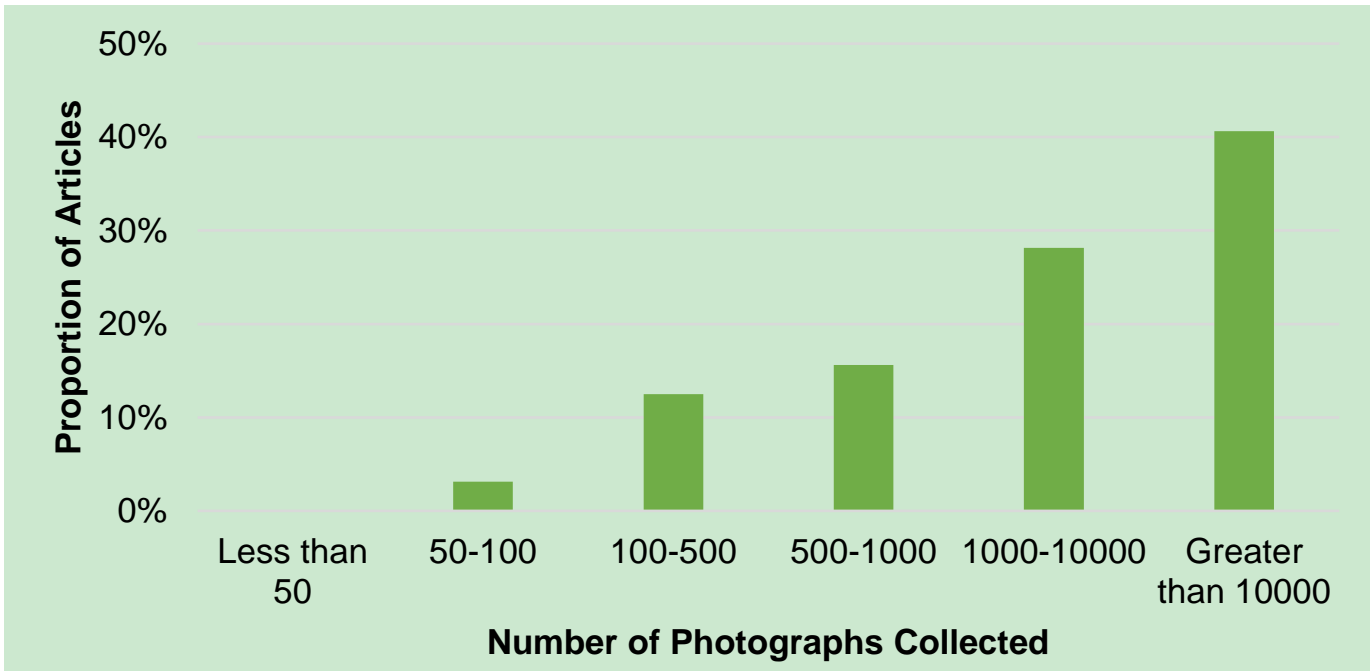

Figure 1: Frequency of sample sizes (number of photographs) for studies based on photographs sourced from online platforms as reported in the peer reviewed articles.

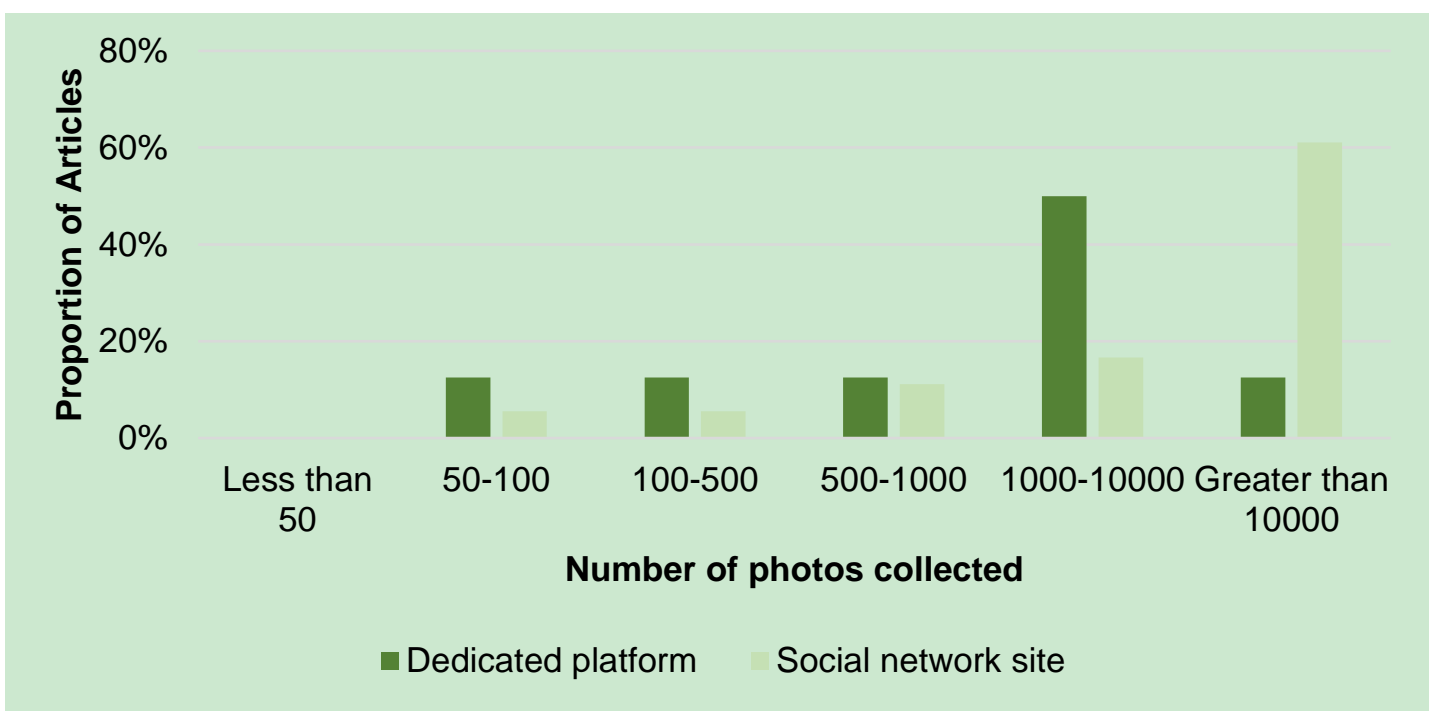

Figure 2: Relationship between online platform (Dedicated vs SNS) and sample size (number of photographs) for studies based on photographs sourced from online platforms. 


\section{Discussion}

\section{Publication trends and geographic distribution}

Markwell (1997), the earliest article included in this review, provides a foundational discussion of tourist-photography research within the context of a nature-based tour. This review highlights how the application of tourist-generated photography has increased steadily since that time, drawing particular interest in the last three years. This increased usage overlaps with the recent and exponential growth of social media and the willingness of people to share photographs via image-sharing applications and internet communities (Barry 2014). This growth mirrors the development of modern citizen science over the same time span (Bonney, Cooper \& Ballard 2016; Liberatore, et al., 2018). With the peak year for publications being 2016, it will be compelling to observe how this trend continues to grow over the next decade with the further evolution of Web 2.0 applications and portable smart devices that enable people to collaborate and share information online (Levin, et al., 2015; Orsi \& Geneletti 2013).

Published studies are geographically distributed in favour of the USA, Australia and the UK. Studies from North America demonstrated a preference towards social research on topics such as visitation rates and tourist perceptions. Ecologically focused research in Australia (and Asia), primarily targeted the distribution and population structure of whale-sharks using tourist-generated photographic data. Interestingly, the three ecological studies from the UK all investigated the use of photographs generated by the public to contribute to the monitoring of bee populations. The limited number of published studies from South America, Africa and Asia highlights a gap in the literature, particularly when these regions contain many of the world's biodiversity hotspots (Myers, et al., 2000). There is, however, possible bias that must be considered when interpreting the dominance of studies undertaken in the USA, Australia and the UK given the inclusion criteria of studies being written in English. Consequently, similar systematic reviews of articles published in languages other than English is worthy of future research.

\section{Collection of photographs}

This review analysed articles that crowdsourced photographs and data from dedicated citizen science online platforms, publicly available SNSs and combinations thereof. Dedicated platforms are developed by researchers to provide an avenue whereby participants can upload relevant images that are analysed by professionals in the field, for example the identification of whale-shark individuals by marine biologists using the platform Wildbook for Whale Sharks (Araujo, et al., 2016; Norman 1999; Norman, et al., 2016). Wildbook is an open source software framework that captures citizen science data, including photographs, to support collaborative mark-recapture and social ecology studies (Wild Me 2016). In October 2016, Wildbook was created after a name change from the former Image Based Ecological Information System (IBEIS) project, which was utilized in Parham's (2015) research to estimate the size of zebra and giraffe populations in Nairobi National Park.

The benefit of dedicated platforms, such as Wildbook, is the increased relevance of the usergenerated information uploaded for the purpose of its incorporation in research compared to SNSs where platforms are often non-specific, differing in purpose, popularity and user-profile (Heikinheimo, et al., 2017). The attraction of using SNSs lies in the ability to facilitate greater participation and reduce the costs of storing photographic records on specialised databases (Stafford, et al., 2010). Limitations however arise in the large degree of 'noise' in data 
collected from SNSs caused by misleading tags and ambiguous visual content (Zhang, et al., 2012). Such errors are often compensated for in these situations by analysing large datasets. As demonstrated in Figure 12, studies sourcing visual content from SNSs are more likely to use a sample size of greater than 10,000 photographs in their analysis, whilst the number of photographs collected on dedicated platforms are more likely to lie between 1000 and 10,000 photographs. It was also found that Flickr is the most frequently used platform amongst SNS-based studies (see Table 2). The published studies justify this selection on the basis that Flickr is a well-established image-sharing platform with more than 8 billion photographs and over 87 million registered users in 2013 (Levin, et al., 2015). In addition, Flickr allows the storing of metadata for the uploaded images, including where the photograph was taken. Users can attach this metadata manually or automatically when using GPS enabled devices such as smartphones and some digital cameras to record geographic information.

The utilisation of geotagged photographs in research was identified in $59 \%$ of studies using online platforms. This feature is particularly useful for studies estimating visitation rates and the presence and interaction of people with natural areas (Hausmann, et al., 2017a; Heikinheimo, et al., 2017; Keeler, et al., 2015; Levin, et al., 2015; Levin, et al., 2017; Orsi \& Geneletti 2013; Richards \& Friess 2015; Sonter, et al., 2016; Straumann, et al., 2014; van Zanten, et al., 2016; Wood, et al., 2013). An alternative application of geo-positioning metadata is for wildlife monitoring programs, as demonstrated in the studies from the UK that use geotagged photographs from Flickr to map the distribution of bees (Kirkhope, et al., 2010; Stafford, et al., 2010). Stafford, et al., (2010) report that the most effective means of implementing such monitoring programs, particularly when funds and time are limited, is the use of a specialist group within the framework of an existing social network such as Flickr.

A key question when crowdsourcing information in this way is who provides the photos? This review demonstrates that the general public provided photographs in $66 \%$ of the included articles. This dominance can be explained by those studies using SNSs to collect and analyse very large datasets. In such cases, it is often difficult to identify the specific character of the people sharing their photographs (i.e. tourists/visitors, tour guides and/or residents). Depending on the focus of the study, knowing this information may not however be a distinction of importance or even necessary. An example of where this information was needed is the research by Straumann, et al., (2014) who compared the photo-taking behaviour of foreign tourists and residents in Zurich, Switzerland. This study examined Flickr user profiles to determine the country of origin of the photographer. Other studies $(27.08 \%)$ that exclusively use images provided by tourists often did not draw information from online platforms, but instead recruited tourists as participants and requested them to take photographs using a supplied camera or by other means (Dorwart, et al., 2009; Hansen 2016; Mackay \& Couldwell 2004; Tonge, et al., 2013). Evidently, such direct contact with study participants is required when identification of who provides the photographs is important, which highlights a potential limitation of using online platforms to source images for social research, for example, as in the case of nature-based tourism studies.

\section{Application to wildlife and tourism research}

\section{Social studies relating to visitors' connection to wildlife}

The distribution of articles was skewed in favour of social studies focusing on visitor's thoughts, behaviours and interactions with nature. These articles explored visitors' 
relationship with nature and wildlife in different ways. A number of studies investigated tourist perceptions about species attractiveness and the cultural benefits of natural area tourism using information drawn from social media (Hausmann, et al., 2017a; Heikinheimo, et al., 2017; Richards \& Friess 2015; Willemen, et al., 2015). Generally, these studies found that social media provided a reliable alternative to survey-based information gathering and gave useful insight into the popularity of certain species and the value of cultural ecosystem services, such as opportunities for wildlife focused recreation. This information can be directed towards management strategies to safeguard biodiversity and certain ecosystem services (Willemen, et al., 2015). Other studies used geotagged content to investigate visitation rates and visitor flows in natural areas (Levin, et al., 2015; Orsi \& Geneletti, 2013; Sonter, et al., 2016; Wood, et al., 2013). These articles revealed that geotagged photographs provide a reliable surrogate for visitor numbers and that as online material grows, crowdsourcing information in this way may open up a new and revolutionary approach to understanding questions about where people recreate in natural areas.

\section{Ecological studies on wildlife}

Ecological studies focusing on the monitoring of species and ecological phenomena accounted for only two out of five (40\%) of the reviewed articles, suggesting that the application of tourist-generated photographs and comments to such research is not being utilized to the extent of social research. The application of tourist-generated photography does however appear to be gaining more momentum in the most recent literature, with most ecological studies (70\%) having been published after 2010 (Figure 7). Currently there is limited diversity in the species targeted by this method, but those that have been studied were often the subject of replicate and/or longitudinal research. This was particularly true for whale sharks (seven articles) and bees (three articles). This trend suggests that once such a citizen science program is established, and has been running for long enough to accumulate enough photographs, it is then possible to conduct numerous studies on the ecology of the target species. For example, all of the Australian ecological studies focused on the citizen science assisted monitoring of whale-sharks (Arzoumanian, et al., 2005; Holmberg, et al., 2008; Holmberg, et al., 2009; Meekan, et al., 2006; Norman 1999; Norman, et al., 2016; Speed, et al., 2007). This breadth of literature on whale-sharks, often incorporating a combination of researcher and publicly volunteered photographic information, provides a case study for the application of this approach for long-term citizen science based ecological monitoring to aid the conservation of other wildlife.

Only $4 \%$ of studies explored the combination of both social and ecological elements in their use of tourist-generated photography. The majority of these studies were review papers discussing the general application of social media and user-generated information in conservation and sustainability science (Di Minin, et al., 2015; Pearson, et al., 2016). Evidently, the application of tourist-generated photographs and comments to research on both wildlife tourism experiences and the monitoring of the wildlife itself is an area that has received little attention in the published literature to this point.

\section{Implications for citizen science and further research}

It was the aim of this systematic review to document how the peer-reviewed literature has utilised tourist-generated photography and photovoice techniques for wildlife research and to explore wildlife based ecotourism experiences. This review identifies different online platforms used to crowdsource photographs, the appropriateness of the platform depending 
on the focus of a study and the different sample sizes attributed to research using dedicated or SNS platforms. This review also provides an overview of the application of touristgenerated data to either social or ecological research. It highlights that little research has been conducted on the application of tourist-generated photography to the combined analysis of both the social and ecological elements of wildlife tourism experiences. Included articles validate the application of crowdsourced geotagged content to map and monitor species distribution and the effectiveness of conducting content analysis on photographs and comments to draw on tourist perceptions. However, few studies address both these elements in the context of wildlife tourism experiences. This approach could be particularly useful for tourist interactions with endangered wildlife, wildlife that has not yet been well researched, or for improving conservation efforts in biodiverse developing countries that may be limited by funding and access to resources (Barve 2014). It was also noted that there are relatively few dedicated review articles on tourist photography in wildlife research, which emphasises the contribution this review makes to the published literature.

Expanding the geographic application of this research to South America, Africa and Asia should be prioritized, particularly considering the highly unique and diverse natural areas found on these continents (Myers, et al., 2000). Given that the literature on this topic is only beginning to emerge, there is great need for more quantitative studies building on the foundational research to improve our understanding and to validate the use of such data sources in wildlife tourism research. Many of the articles reviewed report the need for more studies comparing social media data to data collected by traditional means when using SNSs (Barry 2014) and to further explore potential sources of bias, representation and other limitations in using these technological strategies (Hansen 2016; Heikinheimo, et al., 2017; Keeler, et al., 2015). Applying this approach to different taxonomic groups (Roberge 2014), at different tourism destinations (Mackay \& Couldwell 2004) and to different ecological phenomena (e.g. distribution of blooming flowers) (Zhang, et al., 2012) may also warrant further investigation to determine the potential ecological applications of tourist-generated photography.

\section{Conclusions}

Citizen science approaches are ideally suited to address the broad spectrum for research opportunities identified above. The potential to rapidly engage large numbers of geographically and temporally dispersed individuals to crowdsource environmental data sets using smart-phones, GPS enhanced applications, and SNSs is the essence of modern citizen science practice (Bonney, et al., 2009; Dickinson, Zuckerburg \& Bonter 2010; Eitzel, et al., 2017; Liberatore, et al., 2018; Silvertown 2009). Recruiting, motivating, and retaining participants is however widely acknowledged as a major issue for many citizen science programs (Bonney, et al., 2009; Franzoni \& Sauermann 2014; Liberatore, et al., 2018; Sauermann \& Franzoni 2015; West \& Pateman 2016). Tourism is among the largest sectors in the global economy and demand for varied and exotic ecotourism experiences is a significant driver of that demand (Balmford, et al., 2009; Holden 2016; UNWTO 2017). Utilising the photographs and comments that ecotourists are already voluntarily sharing on SNSs provides access to a largely untapped and continuously refreshed pool of enthusiastic and self-motivated citizen scientists. Many 'professional' or 'academically trained' ecological and tourism researchers are sceptical regarding the creditability of citizen science-based research (Darch, 2014; Freitag, Meyer \& Whiteman 2016; Golumbic, et al., 2017) and especially so for data crowdsourced from SNSs (e g. Barbier, et al., 2012; Senaratne, et al., 
2017; Sui \& Goodchild 2011). This review has however demonstrated that the application of recognised research strategies and data validation techniques (as advocated by authors such as Bonney, et al. 2009; Dickinson, Zuckerburg \& Bonter 2010; and Freitag, Meyer \& Whiteman 2016), along with the analysis of photographs and comments that ecotourists share on SNSs can provide valuable and valid insights for wild life and ecotourism research aligned to the theory and practice of citizen science.

\section{Acknowledgements}

The research project that was the genesis of this review was an international collaboration between the Murdoch University, Borneo Eco Tours (BET), Borneo Ecotourism Solutions and Technologies (BEST) Society, Sukau Rainforest Lodge (SRL), and the Universiti Malaysia Sabah (UMS). We thank our colleague Professor Dr Jennifer Kim Lian Chan of the UMS Borneo Tourism Research Centre for her advice and support for the fieldwork element of our research.

\section{Competing Interests}

The authors have no other competing interests to declare.

\section{Author Contribution}

Obelia Walker and Greg D Simpson have equal contribution to this article.

\section{References}

Araujo, G., Snow, S., So, CS., Labaja, J., Murray, R., Colucci, A. and Ponzo, A. 2016. Population structure, residency patterns and movements of whale sharks in Southern Leyte, Philippines: Results from dedicated photo-ID and citizen science. Aquatic Conservation: Marine and Freshwater Ecosystems, 27(1): 237-252. DOI: https://doi.org/10.1002/aqc.2636

Arzoumanian, Z., Holmberg, J. and Norman, B. 2005. An astronomical pattern matching algorithm for computer-aided identification of whale sharks Rhincodon typus. Journal of Applied Ecology, 42(6): 999-1011. DOI: https://doi.org/10.1111/j.13652664.2005.01117.x

Barry, SJ. 2014. Using social media to discover public values, interests, and perceptions about cattle grazing on park lands. Environmental Management, 53(2): 454-464. DOI: https://doi.org/10.1007/s00267-013-0216-4

Barve, V. 2014. Discovering and developing primary biodiversity data from social networking sites: A novel approach. Ecological Informatics, 24: 194-199. DOI: https://doi.org/10.1016/j.ecoinf.2014.08.008

Barbier, G., Zafarani, R., Gao, H., Fung, G. and Liu, H. 2012. Maximizing benefits from crowdsourced data. Computational and Mathematical Organization Theory, 18(3), 257-279. DOI: https://doi.org/10.1007/s10588-012-9121-2

Basil, M. 2011. Use of photography and video in observational research. Qualitative Market Research: An International Journal, 143(3): 246-257. DOI: https://doi.org/10.1108/13522751111137488

Balmford, A., Beresford, J., Green, J., Naidoo, R., Walpole, M. and Manica, A. 2009. A global perspective on trends in nature-based tourism. PLoS biology, 7(6): e1000144. DOI: https://doi.org/10.1371/journal.pbio.1000144 
Bonney, R., 1996. Citizen science: A lab tradition. Living Bird. 154: 7-15.

Bonney, R., Cooper, C. and Ballard, H. 2016. The theory and practice of citizen science: Launching a new journal. Citizen Science: Theory and Practice, 1(1): 1, 1-4. DOI: https://doi.org/10.5334/cstp.65

Bonney, R., Cooper, CB., Dickinson, J., Kelling, S., Phillips, T., Rosenberg, KV. and Shirk, J. 2009. Citizen science: a developing tool for expanding science knowledge and scientific literacy. BioScience, 59(11): 977-984. DOI:

https://doi.org/10.1525/bio.2009.59.11.9

Carpentier, AS., Jean, C., Barret, M., Chassagneux, A. and Ciccione, S. 2016. Stability of facial scale patterns on green sea turtles Chelonia mydas over time: A validation for the use of a photo-identification method. Journal of Experimental Marine Biology and Ecology, 476: 15-21. DOI: https://doi.org/10.1016/j.jembe.2015.12.003

Chalfen, RM. 1979. Photography's role in tourism: Some unexplored relationships. Annals of Tourism Research, 6(4): 435-447. DOI: https://doi.org/10.1016/0160-7383(79)900069

Collier, J. 1957. Photography in anthropology: A report on two experiments. American Anthropologist, 59(5): 843-859. DOI: https://doi.org/10.1525/aa.1957.59.5.02a00100

Cong, L., Wu, B., Morrison, AM., Shu, H. and Wang, M. 2014. Analysis of wildlife tourism experiences with endangered species: An exploratory study of encounters with giant pandas in Chengdu, China. Tourism Management, 40: 300-310. DOI: https://doi.org/10.1016/j.tourman.2013.07.005

Curtin, S. 2009. Wildlife tourism: The intangible, psychological benefits of human-wildlife encounters. Current Issues in Tourism, 12(5-6): 451-474. DOI: https://doi.org/10.1080/13683500903042857

Curtin, S. and Kragh, G. 2014. Wildlife tourism: Reconnecting people with nature. Human dimensions of wildlife, 19(6): 545-554. DOI: https://doi.org/10.1080/10871209.2014.921957

Darch, P. 2014. Managing the public to manage data: Citizen Science and astronomy. International Journal of Digital Curation, 9(1), 25-40. DOI: https://doi.org/10.2218/ijdc.v9i1.298

Davies, TK., Stevens, G., Meekan, MG., Struve, J. and Rowcliffe J. M. 2012. Can citizen science monitor whale-shark aggregations? Investigating bias in mark-recapture modelling using identification photographs sourced from the public. Wildlife Research, 39(8): 696-704. DOI: https://doi.org/10.1071/WR12092

Dickinson, JL., Zuckerberg, B. and Bonter, DN. 2010. Citizen science as an ecological research tool: challenges and benefits. Annual Review of Ecology, Evolution, and Systematics, 41: 149-72. DOI: https://doi.org/10.1146/annurev-ecolsys-102209144636.

Dickinson, JL., Shirk, J., Bonter, D., Bonney, R., Crain, RL., Martin, J., Philips, T. and Purcell, K. 2012. The current state of citizen science as a tool for ecological research and public engagement. Frontiers in Ecology and the Environment, 10(6): 291-297. DOI: https://doi. org/10.1890/110236 
Di Minin, E., Tenkanen, H. and Toivonen, T. 2015. Prospects and challenges for social media data in conservation science. Frontiers in Environmental Science 3:63. DOI: https://doi.org/10.3389/fenvs.2015.00063

Dorwart, CE., Moore, RL. and Leung, YF. 2006. Visitor employed photography: its potential and use in evaluating visitors' perceptions of resource impacts in trail and park settings. In: Proceedings of the 2006 Northeastern Recreation Research Symposium. Bolton Landing, NY, United States of America on 9-11 April 2006, pp. 307-315.

Dunbar, SG., Hudgins, J. and Jean, C. 2016. Meeting Report for the 1st Photo ID Workshop, 36th Annual Symposium on Sea Turtle Biology and Conservation, Lima, Peru, 29 February 2016. Marine Turtle Newsletter, 151: 32-33.

Eitzel, MV., Cappadonna, JL., Santos-Lang, C, Duerr, RE., Virapongse, A., West, SE., Kyba, CCM, Bowser, A., Cooper, CB., Sforzi, A., Metcalfe, AN., Harris, ES., Thiel, M., Haklay, M., Ponciano, L., Roche, J., Ceccaroni, L., Shilling, FM., Dörler, D., Heigl, F., Kiessling, T., Davis, BY. and Jiang, Q. 2017. Citizen science terminology matters: Exploring key terms. Citizen Science: Theory and Practice, 2(1): 1, p1-20. DOI: https://doi.org/10.5334/cstp.96

Fennell D., 2001: A content analysis of ecotourism definitions. Current Issues in Tourism, 4(5): 403-421. DOI: https://doi.org/10.1080/13683500108667896

Fennell, D., 2008. Ecotourism. Padstow, United Kingdom: TJ International Ltd.

Franzoni, C. and Sauermann, H. 2014. Crowd science: The organization of scientific research in open collaborative projects. Research Policy, 43: 1-20: DOI: https://doi.org/10.1016/j.respol.2013.07.005

Freitag, A., Meyer, R. and Whiteman, L. 2016. Strategies employed by citizen science programs to increase the credibility of their data. Citizen Science Theory and Practice, 1(1): 2, 1-11. DOI: http/dx.doi.org/10.5334./cstp.6

Given, L. M., Opryshko, A., Julien, H. and Smith, J. 2011. Photovoice: A participatory method for information science. Proceedings of the Association for Information Science and Technology, 48(1): 1-3. DOI: https://doi.org/10.1002/meet.2011.14504801209

Golumbic, Y.N., Orr, D. Baram-Tsabari, A. and Fishbain, B. 2017. Between vision and reality: a study of scientists' views on citizen science. Citizen Science: Theory and Practice, 2(1): 6, 1-13. DOI: http://doi.org/10.5334/cstp.53

Hansen, AS. 2016. Testing visitor produced pictures as a management strategy to study visitor experience qualities - A Swedish marine case study. Journal of Outdoor Recreation and Tourism, 14: 52-64. DOI: https://doi.org/10.1016/j.jort.2016.05.001

Hampton, K., Goulet, LS., Rainie, L. and Purcell, K. 2011. Social networking sites and our lives. Pew Internet \& American Life Project. Available at http://www.pewinternet.org/2011/06/16/social-networking-sites-and-our-lives/ [Last accessed 13 May 2018].

Harper, D. 2002. Talking about pictures: A case for photo elicitation. Visual Studies, 17(1): 13-26. DOI: https://doi.org/10.1080/14725860220137345 
Hausmann, A., Toivonen, T., Slotow, R., Tenkanen, H., Moilanen, A., Heikinheimo, V. and Di Minin, E. 2017a. Social media data can be used to understand tourists' preferences for nature-based experiences in protected areas. Conservation Letters, 11(1): 1-10. DOI: https://doi.org/10.1111/conl.12343

Hausmann, A., Toivonen, T., Heikinheimo, V., Tenkanen, H., Slotow, R. and Di Minin, E. 2017b. Social media reveal that charismatic species are not the main attractor of ecotourists to sub-Saharan protected areas. Scientific Reports 7: 763, 1-9. DOI: https://doi.org/10.1038/s41598-017-00858-6

Heikinheimo, V., Minin, ED., Tenkanen, H., Hausmann, A., Erkkonen, J., Toivonen, T. 2017. User-generated geographic information for visitor monitoring in a National Park: A comparison of social media data and visitor survey. ISPRS International Journal of Geo-Information, 6(3): 85. DOI: http://dx.doi.org/10.3390/ijgi6030085

Huertas, A. and Marine-Roig, E. 2015. Destination brand communication through the social media: What contents trigger most reactions of users? In: Tussyadiah, I. and Inversini, A. Information and Communication Technologies in Tourism. Cham, Switzerland: Springer. pp. 295-308.

Holden, A. 2016. An introduction to tourism-environment relationships. In: Gale, T. Ecotourism and Environmental Sustainability: Principles and Practice, London: Routledge, pp. 35-48.

Holmberg, J., Norman, B. and Arzoumanian, Z. 2008. Robust, comparable population metrics through collaborative photo-monitoring of whale sharks Rhincodon typus. Ecological Applications, 18(1): 222-233. DOI: https://doi.org/10.1890/07-0315.1

Holmberg, J., Norman, B. and Arzoumanian, Z. 2009. Estimating population size, structure, and residency time for whale sharks Rhincodon typus through collaborative photoidentification. Endangered Species Research, 7(1): 39-53. DOI: https://doi.org/10.3354/esr00186

Keeler, BL., Wood, SA., Polasky, S., Kling, C., Filstrup, CT. and Downing, JA. 2015. Recreational demand for clean water: evidence from geotagged photographs by visitors to lakes. Frontiers in Ecology and the Environment, 13(2): 76-81. DOI: https://doi.org/10.1890/140124

Kirkhope, CL., Williams, RL., Catlin-Groves, CL., Rees, SG., Montesanti, C., Jowers, J., Stubbs, H., Newberry, J., Hart, AG., Goodenough, AE. and Stafford, R. 2010. Social networking for biodiversity: The BeelD project. In: 2010 International Conference on Information Society, London, United Kingdom on 15 September 2011, pp. 625-626.

Levin, N., Kark, S. and Crandall, D. 2015. Where have all the people gone? Enhancing global conservation using night lights and social media. Ecological Applications, 25(8): 2153-2167. DOI: https://doi.org/10.1890/15-0113.1

Levin, N., Lechner, AM. and Brown, G. 2017. An evaluation of crowdsourced information for assessing the visitation and perceived importance of protected areas. Applied Geography, 79: 115-126. DOI: https://doi.org/10.1016/j.apgeog.2016.12.009

Liberatore, A., Bowkett, E., MacLeod, CJ., Spurr, E. and Longnecker, N. 2018. Social media as a platform for a citizen science community of practice. Citizen Science: Theory and Practice, 3(1): 3, 1-14. DOI: https://doi.org/10.5334/cstp.108 
Lu, W. and Stepchenkova, S. 2012. Ecotourism experiences reported online: Classification of satisfaction attributes. Tourism Management, 33(3): 702-712. DOI: https://doi.org/10.1016/j.tourman.2011.08.003

MacKay, KJ. and Couldwell, CM. 2004. Using visitor employed photography to investigate destination image. Journal of Travel Research, 42(4): 390-396. DOI: https://doi.org/10.1177/0047287504263035

Markwell, K. 1997. Dimensions of photography in a nature-based tour. Annals of Tourism Research, 24(1):131-155. DOI: https://doi.org/10.1016/S0160-7383(96)00053-9

Meekan, MG., Bradshaw, CJA., Press, M., McLean, C., Richards, A., Quasnichka, S. and Taylor J. G. 2006. Population size and structure of whale sharks Rhincodon typus at Ningaloo Reef, Western Australia. Marine Ecology Progress Series, 319: 275-285. DOI: https://doi.org/10.3354/meps319275

Miller, ZD., Quigley, C., Hallo, JC., Dogbey, J., Che. SM. and Seno, SK. 2016. Investigating wildlife and grazing perspectives of Kenyan university students. Journal for Nature Conservation, 32: 44-52. DOI: https://doi.org/10.1016/j.jnc.2016.04.003

Myers, N., Mittermeier, RA., Mittermeier, CG., da Fonseca, GAB. and Kent, J. 2000. Biodiversity hotspots for conservation priorities. Nature, 403: 853-858. DOI: https://doi.org/10.1038/35002501

Nemec Rudež, H. and Vodeb, K. 2015. Students' use of social media during the travel process. Tourism and Hospitality Management, 21(2): 179-190. DOI: https://doi.org/10.20867/thm.21.2.5

Newsome, D., Moore, SA. and Dowling, RK. 2005. Wildlife Tourism. Bristol, UK: Channel View Publications.

Newsome, D., Moore, SA. and Dowling, RK. 2013. Natural area tourism: Ecology, Impacts and Management $2^{\text {nd }}$ ed. Bristol, UK: Channel View Publications.

Noh, J., Lee, K. and Hwang, J. 2017. The effect of motivational factor for using SNSs on tourist attitude. Tourism and Hospitality Management, 23(2) 185-194. DOI: https://doi.org/10.20867/thm.23.2.5

Norman, BM. 1999. Aspects of the biology and ecotourism industry of the whale shark Rhincodon typus in northwestern Australia. Thesis (PhM), Murdoch University. Available at: http://researchrepository.murdoch.edu.au/view/student/thesis/Norman=3ABradley_ Michael=3A=3A.html [Last accessed 22 July 2018].

Norman, BM., Reynolds, S. and Morgan, DL. 2016. Does the whale shark aggregate along the Western Australian coastline beyond Ningaloo Reef? Pacific Conservation Biology, 22(1): 72-80. DOI: https://doi.org/10.1071/PC15045

Oteros-Rozas, E., Martín-López, B., Fagerholm, N., Bieling, C. and Plieninger, T. 2017. Using social media photos to explore the relation between cultural ecosystem services and landscape features across five European sites. Ecological Indicators, DOI: https://doi.org/10.1016/j.ecolind.2017.02.009 
Orsi, F. and Geneletti, D. 2013. Using geotagged photographs and GIS analysis to estimate visitor flows in natural areas. Journal for Nature Conservation, 21(5): 359-368. DOI: https://doi.org/10.1016/j.jnc.2013.03.001

Orsini, JP. and newsome, D. 2005. Human perceptions of hauled out Australian sea lions (Neophoca cinerea) and implications for management: a case study from Carnac Island, Western Australia. Tourism in Marine Environments, 2(1), 129-132. DOI: https://doi.org/10.3727/154427305774865769

Palomino, M., Taylor, T., Göker, A., Isaacs, J. and Warber, S. 2016. The online dissemination of nature-health concepts: lessons from sentiment analysis of social media relating to "Nature-Deficit Disorder". International Journal of Environmental Research and Public Health, 13(1): 142, 1-23. DOI: http://dx.doi.org/10.3390/ijerph13010142

Parham, JR. 2015. Photographic censusing of Zebra and Giraffe in the Nairobi National Park. Thesis (Masters), Rensselaer Polytechnic Institute. Available at https://search.proquest.com/docview/1761862733?pq-origsite=gscholar [Last accessed 23 July 2018].

Patroni, J., Day, A., Lee, D., Chan, JKL., Kerr, D., Newsome, D., and Simpson, GD. 2017. Looking for evidence that place of residence influenced visitor attitudes to feeding wild dolphins. Tourism and Hospitality Management, (24)1: 87-105. DOI: https://doi.org/10.20867/thm.24.1.2

Patroni, J., Simpson, G. and Newsome, D. 2018. Feeding wild fish for tourism - A systematic quantitative literature review of impacts and management. International Journal of Tourism Research, 20(3): 286-298. DOI: https://doi.org/10.1002/jtr.2180

Pearson, E., Tindle, H., Ferguson, M., Ryan, J. and Litchfield, C. 2016. Can we tweet, post, and share our way to a more sustainable society? A review of the current contributions and future potential of \#Socialmediaforsustainability. Annual Review of Environment and Resources, 41: 363-397. DOI: https://doi.org/10.1146/annurevenviron-110615-090000

Pickering, C. and Byrne, J. 2014. The benefits of publishing systematic quantitative literature reviews for PhD candidates and other early-career researchers. Higher Education Research \& Development, 33(3): 534-548. DOI: https://doi.org/10.1080/07294360.2013.841651

Pickering, C., Grignon, J., Steven, R., Guitart, D. and Byrne, J. 2015. Publishing not perishing: How research students transition from novice to knowledgeable using systematic quantitative literature reviews. Studies in Higher Education, 40(10): 17561769. DOI: https://doi.org/10.1080/03075079.2014.914907

Prakash, TGSL., Perera, PKP., Newsome, D. and Kusuminda, TGT. 2017. Reasons for visitor dissatisfaction in National Parks based tourism in Sri Lanka. In: Climate Change and Conservation, WILDLANKA International Symposium, Colombo, Sri Lanka on 15-16 August 2017.

Prakash, SL., Perera, P., Newsome, D., Kusuminda, T. and Walker, O. 2018. Reasons for visitor dissatisfaction with wildlife tourism experiences at highly visited national parks 
in Sri Lanka. Journal of Outdoor Recreation and Tourism. DOI: https://doi.org/10.1016/j.jort.2018.07.004

Richards, DR. and Friess, DA. 2015. A rapid indicator of cultural ecosystem service usage at a fine spatial scale: Content analysis of social media photographs. Ecological Indicators, 53: 187-195. DOI: https://doi.org/10.1016/j.ecolind.2015.01.034

Roberge, JM. 2014. Using data from online social networks in conservation science: Which species engage people the most on Twitter? Biodiversity and Conservation, 23(3): 715-726. DOI: https://doi.org/10.1007/s10531-014-0629-2

Sauermann, H. and Franzoni, C. 2015. Crowd science user contribution patterns and their implications. Proceedings of the National Academy of Sciences, 112(3): 679-84. DOI: https://doi.org/10.1073/pnas.1408907112

Senaratne, H., Mobasheri, A., Ali, AL., Capineri, C. and Haklay, M. 2017. A review of volunteered geographic information quality assessment methods. International Journal of Geographical Information Science, 31(1): 139-167. DOI: https://doi.org/10.1080/13658816.2016.1189556

Sessions, C., Wood, SA., Rabotyagov, S. and Fisher, DM. 2016. Measuring recreational visitation at U.S. National Parks with crowd-sourced photographs. Journal of Environmental Management, 183(3): 703-711. DOI: https://doi.org/10.1016/j.jenvman.2016.09.018

Sieber, RE. and Haklay, M. 2015. The epistemology(s) of volunteered geographic information: A critique. Geo: Geography and Environment, (2)2: 122-136. DOI: https://doi.org/10.1002/geo2.10

Silvertown, J., 2009. A new dawn for citizen science. Trends in Ecology \& Evolution, 24(9): 467-471. DOI: https:// doi.org/10.1016/j.tree.2009.03.017

Soleri, D., Long, JW., Ramirez-Andreotta, MD., Eitemiller, R. and Pandyall, R. 2016. Finding pathways to more equitable and meaningful public-scientist partnerships. Citizen Science: Theory and Practice, 1(1): 9, 1-11. DOI: http://dx.doi.org/10.5334/cstp.46

Sonter, LJ., Watson, KB., Wood, SA. and Ricketts, TH. 2016. Spatial and temporal dynamics and value of nature-based recreation, estimated via social media. PLOS ONE, 11(9): e0162372. DOI: https://doi.org/10.1371/journal.pone.0162372

Speed, CW., Meekan, MG. and Bradshaw, C. 2007. Spot the match - wildlife photoidentification using information theory. Frontiers in Zoology, 4:2. DOI: https://doi.org/10.1186/1742-9994-4-2

Stafford, R., Hart, AG., Collins, L., Kirkhope, CL., Williams, RL., Rees, SG., Lloyd, JR. and Goodenough, AE. 2010. Eu-Social Science: The role of internet social networks in the collection of bee biodiversity data. PLOS ONE, 5(12). e14381. DOI: https://doi.org/10.1371/journal.pone.0014381

Straumann, RK., Çöltekin, A. and Andrienko, G. 2014. Towards (re)constructing narratives from georeferenced photographs through visual analytics. The Cartographic Journal, (51)2: 152-165. DOI: https://doi.org/10.1179/1743277414Y.0000000079 
Sui, D. and Goodchild, M. 2011. The convergence of GIS and social media: challenges for GIScience. International Journal of Geographical Information Science, 25(11), 17371748. DOI: https://doi.org/10.1080/13658816.2011.604636

Tenkanen, H., Di Minin, E., Heikinheimo, V., Hausmann, A., Herbst, M., Kajala, L. and Toivonen, T. 2017. Instagram, Flickr, or Twitter: Assessing the usability of social media data for visitor monitoring in protected areas. Scientific Reports, 7: 17615, 111. DOI:10.1038/s41598-017-18007-4.

Tonge, J., Moore, SA., Ryan, MM and Beckley, LE. 2013. A photo-elicitation approach to exploring the place meanings ascribed by campers to the Ningaloo Coastline, northwestern Australia. Australian Geographer, 44(2): 143-160. DOI: https://doi.org/10.1080/00049182.2013.789591

United Nations World Tourism Organisation (UNWTO). 2017. UNWTO Tourism Highlights: 2017 Edition. Mardid, Spain: UNWTO. DOI: https://doi.org/10.18111/9789284419029

van Dijck, J., 2013. The culture of connectivity: A critical history of social media. Oxford, England: Oxford University Press.

van der Wal, R., Anderson, H., Robinson, A., Sharma, N., Mellish, C., Roberts, S., Darvill, B. and Siddharthan, A. 2015. Mapping species distributions: A comparison of skilled naturalist and lay citizen science recording. Ambio, 44(4): 584-600. DOI: https://doi.org/10.1007/s13280-015-0709-x

van Zanten, BT., van Berkel, DB., Meentemeyer, RK., Smith, JW., Tieskens, KF. and Verburg, PH. 2016. Continental-scale quantification of landscape values using social media data. Proceedings of the National Academy of Sciences of the United States of America, 113(46): 12974-12979. DOI: https://doi.org/10.1073/pnas.1614158113

Vantieghem, P., Maes, D., Kaiser, A. and Merckx, T. 2016. Quality of citizen science data and its consequences for the conservation of skipper butterflies (Hesperiidae) in Flanders (northern Belgium). Journal of Insect Conservation, 21(3): 451-463. DOI: https://doi.org/10.1007/s10841-016-9924-4

Walden-Schreiner, CA. 2017. Integrating geospatial resource use and environmental data at varying scales for protected area conservation. Thesis $(\mathrm{PhD})$, North Carolina State University. Available at https://repository.lib.ncsu.edu/bitstream/handle/1840.20/33687/etd.pdf?sequence=1 [Last accessed 23 July 2017].

Walden-Schreiner, C., Rossi, SD., Barros, A., Pickering, C. and Leung, Y. 2018. Using crowd-sourced photos to assess seasonal patterns of visitor use in mountainprotected areas. AMBIO. DOI: https://doi.org/10.1007/s13280-018-1020-4

Wang, C. and Burris, MA. 1997. Photovoice: Concept, methodology, and use for participatory needs assessment. Health Education \& Behavior, 24(3): 369-387. DOI: https://doi.org/10.1177/109019819702400309

Weaver, D., 2008. Ecotourism. 2nd ed. Milton, Australia: Wiley Australia.

West, SE. and Pateman, RM. 2016. Recruiting and retaining participants in citizen science: what can be learned from the volunteering literature? Citizen Science: Theory and Practice, 1(2), 15, 1-10. DOI: https://doi.org/10.5334/cstp.8 
White, RL., Sutton, AE., Salguero-Gómez, R., Bray, TC., Campbell, H., Cieraad, E., Geekiyanage, N., Gherardi, L., Hughes, AC., Søgaard Jørgensen, P., Poisot, T., DeSoto, L. and Zimmerman, N. 2015. The next generation of action ecology: novel approaches towards global ecological research. Ecosphere 6(8): 134, 1-16. DOI: https://doi.org/10.1890/ES14-00485.1

Wild Me. 2016. Wildbook for Wildlife Data Management. Available at http://www. wildbook.org/doku.php [Last accessed 21 July 2018].

Willemen, L., Cottam, AJ., Drakou, EG. and Burgess, ND. 2015. Using social media to measure the contribution of Red List species to the nature-based tourism potential of African protected areas. PLOS ONE, 10(6): e0129785. DOI: https://doi.org/10.1371/journal.pone.0129785

Wood, S., Guerry, AD., Silver, JM. and Lacayo, M. 2013. Using social media to quantify nature-based tourism and recreation. Scientific Reports, 3: 2976, 1-7. DOI: https://doi.org/10.1038/srep02976

Yi-Frazier, JP., Cochrane, K., Mitrovich, C., Pascual, M., Buscaino, E., Eaton, L., Panlasigui, N., Clopp, B. and Malik, F. 2015. Using Instagram as a modified application of photovoice for storytelling and sharing in adolescents with Type 1 Diabetes. Qualitative Health Research, 25(10): 1372-1382. DOI: https://doi.org/10.1177/1049732315583282

Zavodna, LS. and Zavodny Pospisil, J. 2018. Social media use among Czech university students during the travel process. Tourism and Hospitality Management, 24(1:213227. DOI: https://doi.org/10.20867/thm.24.1.7

Zeglin, RJ. and Mitchell, J. 2014. Using social media to assess conceptualizations of sexuality. American Journal of Sexuality Education, 9(3): 276-291. DOI: https://doi.org/10.1080/15546128.2014.933994

Zhang, H., Korayem, M., Crandall, D. and LeBuhn, G. 2012. Mining photo-sharing websites to study ecological phenomena. In: Proceedings of the 21st International Conference on World Wide Web, Lyon, France, 16-20 April 2012, pp 749-758. 